Рад примљен: 10.07 .20
Рад прихвћћен: 14.09.
КОНСТИТУЦИОНАЛИЗАЦИЈА ПРАВА НА
ПРЕДУЗЕТНИШТВО И СА ЊИМ ПОВЕЗАНИХ ПРАВА

Апстракт: Овај прилог је радна основа за сагледавање уставних гаранщија и начина уставног регулисања развојних ресурса и капацитета друштва у компаративној уставности. Циљ због кога је овај прилог припремљен је увид у искуства компаративне уставности и начин на који се у уставима регулишу питања значајна за развој друштва, како би се у контексту решења која садржи Устав Републике Србије унапредило уставно регулисање развојних питања. Као кључно питање значајно за сагледавање конституционализације развојних питања издвојено је посебно уставно регулисање права на предузетништво и привређивање, обим и садржај уставног гарантовања ових права уз акценат на ограничења ових права, посебно ограничења која почивају на једнако значајним правима праву на здрав живот и здраву животну средину која укључују и заштиту природних ресурса и животне средине.

Као примери компаративне уставности коришћени су устави: Аустрије, Белгије, Бугарске, Босне и Херцеговине, Црне Горе, Данске, Франиуске, Хрватске, Италије, Македоније, Немачке, Пољске, Русије, Републике Српске, Словеније, Словачке, Србије, Швајцарске и Шпаније. При избору устава чије су одредбе обухваћене истраживањем, водило се рачуна да се задовољи неколико критеријума, а пре свега: да избор обухвати уставе чланица Европске уније, уставе бивших социјалистичких држава које су сада чланице Европске уније, уставе земаља окружења, уставе земаља које су у процесу преговора са европском унијом и уставе земаља са којима је Србија, све до распада СФРЈ била у заједничкој држави. Овакав избор устава омогућује да се

$\overline{\text { *pajmar@gmail.com }}$ 
у различитим друштвеним и политичким контекстима у којима су обликована уставна правила, сагледају конкретна уставна решења у ширем светлу и омогући целовитији увид у ова решења.

Кључне речи: Компаративно уставно право, право на предузетништво, људска права.

\section{1. Гарантовање слободе предузетништва}

Слободу предузетништва начелно гарантује највећи број устава који су били предмет анализе. Приступи уставном регулисању предузетништва се разликују с обзиром на то на који начин устави одређују предузетништво, да ли се предузетнишво гарантује самостално или уз нека друга са њим повезана права и слободе, контекст у коме се гарантује предузетништво. Увид у уставна решења омогућује да се изнесу основна запажања о уставним гаранцијама права на предузетништво.

1. Највећи број анализираних устава гарантује слободу предузетништва ${ }^{1}$, а поједини устави гарантују слободу привредне иницијативе ${ }^{2}$ или слободу привређивања. ${ }^{3}$ У овом случају терминиологија која се у уставу користи није споредно, већ суштинско питање. Слобода предузетништва је шири појам, јер осим слободе привредне иницијативе укључује и иницијативу у другим, не мање значајним областима друштвеног живота.

2. Слобода предузетништва се гарантује као једна од темељних вредности уставног система, поред начела владавине права, правне заштита својине, хуманизма, социјалне правде и сигурности, хуманизације простора и унапређења и поштовања животне средине ${ }^{4}$, као самостално право или уз друге са њом повезане слободе или права. Најчешће се слобода предузетништва повезује са слободом тржишта (тржишном привредом) ${ }^{5}$ и гарантује уз ову слободу, али и уз отвореност тржишта', слободу

1 Устави Црне Горе (чл. 139), Босне и Херцеговине (преамбула ст. 1), Хрватске (чл. 49, ст. 1), Македоније (чл. 8, ст. 1, алинеја 7 и чл. 55, ст. 1), Србије (чл. 82, ст. 1 и чл. 83, ст. 1), Републике Српске (чл. 5, ст. 1, алинеја 6).

2 Устави Бугарске (чл. 19, ст. 1) и Словеније (чл. 74, ст. 1).

3 Устав Републике Српске (чл. 50).

4 Устав Босне и Херцеговине (Праамбула ст. 4), Македоније (члан 8, став 1, алинеја $3,6,7,8$ и 10).

5 Устави Црне Горе (члан 139), Хрватске (члан 49, став 1), Македоније (члан 8, став 1, алинеја 7 и члан 55, став 1), Србије (члан 5, став 1 , члан 82, став 1 ).

6 Устави Црне Горе (члан 139) и Србије (члан 132, став 1). 
конкуренције, ${ }^{7}$ самосталност привредних субјеката, ${ }^{8}$ одговорност привредних субјеката за преузете обавезе, ${ }^{9}$ равноправност свих облика својине ${ }^{10}$ и заштиту приватне и свих других облика својине.

3. Општи контекст у коме се гарантује право на предузетништво је показатељ који не говори само о основама на којима почива економија и привређивање, већ и о основним принципима који опредељују природу политичке заједнице. Кључно питање је да ли се ради о заједници либералног или заједници либерално демократског типа. Другим речима, да ли се поред тржишне привреде (слободно и отворено тржиште, слобода приватне иницијативе, слобода конкуренције и др. ${ }^{11}$ прихвата и принцип социјалне правде и оба принципа конституционализују као темељни принципи на којима почива заједница. Консеквенце оваквог приступа огледају се и у садржају уставног регулисања слободе предузетништва.

Устави начелно гарантују и штите слободу предузетништва и привређивања у оквиру тржишне привреде, али ову начелну гаранцију прате и ограничења која постављају оквире у којима се она реализује. Подела устава на либералне и либерално демократске ослоњена само на јемство слободе предузетништва није увек поуздана, јер уставна решења нису увек консеквентна и нису јасно повезана са принципом социјалне правде који велики број устава такође гарантује. Принцип социјалне правде често није у корелацији са уставним гаранцијама слободе предузетништва. У прилог оваквом закључку говоре и уставна решења о

7 Устав Црне Горе (члан 139)

8 Устави Црне Горе (члан 139), Србије (члан 132, став 1), Републике Српске (члан 50).

9 Устав Црне Горе (члан 139)

10 Устави Црне Горе (члан 139) и Србије (члан 132, став 1).

11 Нпр. Устав Бугарске (члан 19, став 1) прописује да „економија Републике Бугарске почива на слободној привредној иницијативи“; Устав Црне Горе (члан 139) прописује да се „економско уређење заснива на слободном и отвореном тржишту, слободи предузетништва и конкуренције, самосталности привредних субјеката и њиховој одговорности за преузете обавезе у правном промету, заштити и равноправности свих облика својине“; Устав Хрватске (члан 41, став 1) утврђује да су „Подузетничка и тржишна слобода темељ господарског устроја Републике Хрватске“; Устав Србије (члан 82 , став 1) прописује да „економско уређење у Републици Србији почива на тржишној привреди, отвореном и слободном тржишту, слободи предузетништва, самосталности привредних субјеката и равноправности приватне и других облика својине“; Устав Републике Српске (члан 50) прописује да „Економско и социјално уређење заснива се на равноправности свих облика својине и слободном привређивању, самосталности предузећа и других облика привређивања у стицању и расподјели добити и слободном кретању робе, рада и капитала у Републици као јединственом привредном простору.“ 
разлозима ограничења слободе предузетништва, ${ }^{12}$ и мерама које држава може предузети како би обезбедила остваривање друштвеног (јавног) интереса, економску сигурност и социјално благостање грађана.

Овометребадодати да сеусавременојуставности, поредпринципа социјалне правде који може бити основ за ограничење права на предузетништво, спорадично срећу и примери конституционализације још једног основа за ограничавање слободе предузетништва. То је очување, унапређење и заштита животне средине као предуслов остваривања права на здраву животну средину.

\section{2. Посебне уставне гаранције значајне за остваривање слободе предузетништва}

Поред начелног гарантовања слободе предузетништва, примери компаративне уставности показују да се уставом посебно гарантује и регулише више важних питања која су претпоставке за остваривање слободе предузетништва. То се посебно односи на:

Основне претпоставке које слободу предузетништва чине могућом, као што су нпр: експлицитно уставно и законско гарантовање једнаких правних услова за обављање привредних делатности ${ }^{13}$, самосталност привредних субјеката $^{14}$, слободно кретање роба, услуга и финансијских средстава ${ }^{15}$, развијање конкуренције и подршка конкуренцији ${ }^{16}$ као и антимонополска клаузула, одговорност привредних субјеката за преузете обавезе у правном промету ${ }^{17}$ и др.

Антимонополску клаузулу која представља важно јемство слободе предузетништва регулише велики број устава који су анализирани. Начин на који је у уставима регулисана антимонополска клаузула показује да међу уставима постоје извесне разлике. У већем броју устава изричито се забрањује: нарушавање и ограничавање слободне конкуренције, нелојална конкуренција и подстицање неравноправног, монополског или

12 Нпр. устави Црне Горе (члан 59), Хрватске (члан 50, став 2), Македоније (члан 55, став 3), Србије (члан 83, став 2).

13 Устави Бугарске (члан 19, став 2), Хрватске (члан 49, став 2), Македоније (члан 55, став 2), Србије (члан 84, став 1).

14 Устав Црне Горе (члан 139).

15 Устав Србије (члан 82, став 2).

16 Устави Црне Горе (члан 139) и Русије (члан 8, став 1).

17 Устав Црне Горе (члан 139). 
доминантног положаја на тржишту ${ }^{18}$, ограничавање слободне конкуренције и нелојална конкуренција, ${ }^{19}$ акти којима се, супротно закону, ограничава слободна конкуренција стварањем или злоупотребом монополског или доминантног положаја ${ }^{20}$, злоупотреба монополског положаја чије облике и садржај ближе регулише закон. ${ }^{21}$ Поједини устави прописују обавезе државе да спречава злоупотребу монополизма и нелојалну конкуренцију 22 као и да предузима мере против монополског положаја и понашања на тржишту ${ }^{23}$.

Посебно гарантовање одређених права страних физичких и правних лища везаних за слободу предузетништва карактеристика је само малог броја устава који су били предмет анализе. Странцима се гарантује: исти положај на тржишту као и домаћим држављанима, ${ }^{24}$ једнака законска заштита инвестиција и привредне делатности ${ }^{25}$, слободно изношење добити и уложеног капитала ${ }^{26}$, изричито се гарантује да се права странаца стечена на основу уложеног капитала не могу умањити законом или другим прописом. ${ }^{27}$

Јединство економског простора које регулише само неколико анализираних устава, било начелном нормом која прописује да је територија државе јединствен економски или привредни простор ${ }^{28}$, или поред ове опште одредбе и устав ближе регулише да се то јединство односи на тржиште роба, рада, капитала и услуга ${ }^{29}$, односно да се оно односи на слободно кретање роба, услуга и финансијских средстава, подршку конкуренцији, слободну привредну активност. ${ }^{30}$

18 Устав Црне Горе (члан 40, став 3).

19 Устав Словеније (члан 74, став 3).

20 Устав Србије (члан 84, став 3).

21 Устав Хрватске (члан 149, став 2).

22 Устав Бугарске (члан 19, став 2).

23 Устав Македоније (члан 55, став 2).

24 Устав Србије (члан 84, став 4).

25 Устав Бугарске (члан 19, став 3).

26 Устави Хрватске (члан 49, став 4) и Македоније (члан 59).

27 Устав Македоније (члан 59).

28 Устав Црне Горе (члан 140, став 1), Устав Швајцарске (члан 95, став 1).

29 Устав Србије (члан 82, став 2).

30 Устав Русије (члан 8, став 1). 


\section{3. Ограничење слободе предузетништва}

Уз гарантовање слободе предузетништва и основних претпоставки које се односе на креирање амбијента који омогућује остваривање ове слободе, у свим уставима који су били предмет анализе прописана су и извесна ограничења ове слободе, разлози који су основ за могућа ограничења слободе предузетништва као и услови под којима су ограничења легитимна и допуштена.

Разлози који могу бити основ за ограничења слободе предузетништва регулишу се уставом, што сведочи и потврђује значај који ова питања имају у правном систему, будући да их регулише највиши правни акт. Анализа компаративне уставности показује да устави прописују различите разлоге за ограничење права на предузетништво. Као разлози који су основ да се слобода предузетништва подвргне ограничењима наводе се: заштита здравља људи ${ }^{31}$, заштита животне средине ${ }^{32}$, заштита природних богатстава и природе $\mathrm{e}^{33}$, заштита културне баштине $\mathrm{e}^{34}$, заштита безбедности и одбране земље, ${ }^{35}$ заштита јавног интереса. ${ }^{36}$

\section{4. Заштита права на предузетништво}

Само у неким од анализиранихустава, у самом уставу изричито се регулише и законска заштита слободе предузетништва као и слобода привређивања и инвестирања. То је, између осталог, и показатељ статуса који у уставу има право на предузетништво у поређењу са другим људским правима. C обзиром на место на коме су у уставима систематизоване одредбе о праву на предузетништво може се закључити да је још увек отворено питање да ли је право на предузетништво индивидуално људско право или припада сету уставних правила која регулишу економско уређење.

Анализа компаративне уставности показује да међу уставима који регулишу ову материју постоје разлике с обзиром на садржај и обим

31 Устави Црне Горе (члан 59), Хрватске (члан 50, став 2), Македоније (члан 55, став 3), Србије (члан 83, став 2).

32 Устави Црне Горе (члан 59), Хрватске (члан 50, став 2), Македоније (члан 55, став

3), Србије (члан 83, став 2).

33 Устави Црне Горе (члан чл. 59), Хрватске (члан чл. 50, став 2), Македоније (члан чл. 55, став 3), Србије (члан чл. 83, став 2).

34 Устав Црне Горе (члан 59).

35 Устави Црне Горе (члан 59), Хрватске (члан 50, став 2), Македоније (члан 55, став

3), Србије (члан 83, став 2).

36 Устав Словеније (члан 74, став 3). 
уставне регулативе. У неким од устава ове слободе се начелно гарантују како домаћим држављанима тако и странцима. Други садрже експлицитне одредбе о праву странаца на предузетништво и условима под којима ови то право могу остваривати, ${ }^{37}$ или експлицитно прописују да се права стечена улагањем капитала не могу умањити законом нити другим правним актом. ${ }^{38}$

\section{5. Заштита потрошача}

У контекстугарантовања слободе предузетништва, примери компаративне уставности показују да је заштита потрошача постала уставна материја. У уставу се, дакле, посебно регулише и заштита потрошача, а уставне одредбе о заштити потрошача представљају својеврсне, уставом прописане границе у оквирима којих се гарантује слобода предузетништва. Примери компаративне уставности показују да границе слободи предузетништва постављају људска права као и да се слобода предузетништва може остваривати само на начин који не нарушава уставом гарантована људска права. Стога би се могло рећи да основна људска права имају примат над слободом предузетништва као и да су људска права и својеврсно ограничење слободе предузетништва.

С обзиром на садржај уставног регулисања заштите потрошача устави се разликују. У већини анализираних устава, уз начелну норму која се односи на заштиту потрошача ${ }^{39}$ експлицитно се прописује обавеза државе да штити потрошаче и забрањују се радње којима се нарушава здравље, безбедност и приватност потрошача. ${ }^{40}$

\section{6. Принцип социјалне правде у контексту слободе предузетништва}

Устави у којима принцип социјалне правде, поред принципа владавине права, представља један од темељних принципа на којима почива заједница, следећи тај принцип регулишу и обавезе државе у вези са слободом предузетништва. То се посебно односи на обавезе државних власти у вези са слободом предузетништва и привредним развојем, заштитом положаја запослених, кооперацијом, удруживањем и др.

37 Устав Бугарске (члан 19, став 3).

38 Устави Хрватске (члан 49, став 4) и Србије (члан 84, став 3).

39 Устав Бугарске који заштиту потрошача регулише у контексту гарантовања једнаких услова привређивања свим грађанима и правним лицима (члан 14 став 2) и Републике Српске (чл. 52).

40 Устави Црне Горе (члан 70), Србије (члан 90, став 2), Републике Српске (члан 53). 
Уставна решења су различита пре свега с обзиром на то на која питања устав ставља фокус и колико детаљна је уставна регулатива. Акценат је на следећим питањима:

- Државни подстицаји за привредни развој и социјално благостање $\mathrm{e}^{41}$

- $\quad$ Равномерни привредни развој свих крајева ${ }^{42}$

- Социјални дијалог између синдиката и послодаваца као начин и инструмент усклађивања утицаја тржишне привреде на социјални и економски положај запослених ${ }^{43}$

- Кооперација и удруживање грађана и правних лица ради постизања привредног и социјалног напретка ${ }^{44}$

- Законом прописани програми погодни за управљање и координирање јавне и приватне економске делатности у друштвене сврхе ${ }^{45}$

- Очување интереса целокупне привреде и допринос благостању и економској сигурности становништва ${ }^{46}$

- $\quad$ Стварање повољних услова за привређивање $\mathrm{e}^{47}$

- Унапређење заједничког благостања, сталног развоја, унутрашњег заједништва и културне разноликости ${ }^{48}$

- Обавезе јавних власти да обезбеде модернизацију привредних сектора уз експлицитно навођење појединих сектора (пољопривреда, сточарство, риболов, занатство, планинска подручја) ${ }^{49}$

- Планирање опште привредне активности у циљу обезбеђења колективних потреба, уравнотежења и хармонизације регионалног и секторског развоја и подстицања пораста прихода и богатства као и његове правичне расподеле ${ }^{50}$ и регулисање начина израде ових

41 Устав Хрватске (члан 49, став 3).

42 Устави Бугарске (члан 19), Хрватске (члан 49, став 3), Македоније (члан 57).

43 Устав Србије (члан 82, став 3).

44 Устав Бугарске (члан 19, став 4).

45 Устав Италије (члан 41, став 3)

46 Устав Швајцарске (члан 94, став 2).

47 Устав Швајцарске (члан 94, став 3).

48 Устав Швајцарске (члан 2, став 2).

49 Устав Шпаније (члан 130, став 1).

50 Устав Шпаније (члан 131, став 1). 
планова у партиципативном процесу у коме суделују различити субјекти а координира их посебно тело формирано на основу устава ${ }^{51}$

- Подстицаји и програми заунапређење и помоћ задругарствуу контролу сврхе и карактера задругарства ${ }^{52}$

- Подношење законских предлога који се односе на планове и програме економског и социјалног карактера Социјалном и економском савету кога влада консултује о тим питањима. ${ }^{53}$

\section{7. Право на здрав живот и здраву животну средину и природни развојни ресурси као основ ограничења права на предузетништво}

Конституционализација права на здрав живот и здраву животну средину, еколошких и са њима повезаних права је новија појава у савременој уставности. Као што су социјално-економска права, која данас гарантује велики број устава, била новум у уставности у првој половини XX века, тако је конституционализација права која припадају четвртој генерацији новум у савременој уставности. Још нису обликовани стандарди у конституционализацији ове материје, а решења у компаративној уставности се значајно разликују по: приступу уставној регулативи (контекст основних људских права или обавеза државе); одређењу садржине права (право на здрав живот, здрава животна средина, еколошка права, право на информисање о стању животне средине, одговорност за штету нанету животној средини); обиму регулативе (бланкетне или конкретне норме); садржају уставне регулативе (квалитет и обим гаранција, прецизирање права и обавеза и др.) и др. Разлози за „лутање“ уставне регулативе можда су и у томе што је ова материја нашла место у уставима под утицајем међународних извора права у којима још нису обликовани чврсти стандарди у правно обавезујућим међународним конвенцијама, већ се они постепено обликују у међународним документима стратешке природе (стратегије, акциони планови) који посредно утичу на формирање правних стандарда.

Решења у компаративној уставности су различита по: садржини; систематизацији у различитим поглављима устава (људска права, дистрибуција надлежности везаних за право на здраву животну средину и

51 Устави Немачке (члан 91 а став 3) и Шпаније (члан 131, став 2).

52 Устав Италије (члан 45) који изричито утврђује да држава признаје друштвену функцију задругарства које има карактер узајамног помагања а не циљ приватне шпекулације.

53 Устав Француске (чл. 76 - ревизије Устава из 1993, 1995, 1998, 1999, 2000 и 2003). 
области које су релевантне за животну средину између различитих нивоа власти и др.); обиму регулативе која се креће од општих норми (свако има право / свако је дужан) до регулисања одговорности за заштиту животне средине (обавеза јавних власти / обавеза власти и грађана); различитим природним ресурсима значајним за животну средину и развој који се посебно наводе и др. То говори да ова материја још увек трага за својим правим местом у уставној регулативи.

Неколико питања издвајају се с обзиром на значај и утицај који имају на ограничење слободе предузетништва.

1. Право на здраву животну средину као одговорност јавних власти према будућим генерацијама је полазна и темељна претпоставка ограничења права на предузетништво. У том контексту указујемо на примере компаративне уставности који као једну од темељних вредности уставног поретка наводе „уређење и хуманизацију простора и унапређење и поштовање животне средине“54, или на различите начине конституционализују принцип одрживог развоја као обавезу централних и регионалних власти да предузимају активности како би се „створио један трајан и одмерен однос између природе и њене способности обнављања с једне стране и коришћења од стране људи с друге стране“55; прописују обавезу јавних власти да воде „политику која гарантује еколошку сигурност садашњим и будућим поколењима“56; демонстрирају свест о „одговорности према будућим генерацијама“ и обавезују државу да „законом и спровођењем других мера штити природна добра“"57 и животну средину.

2. Очување и заштита животне средине као основ ограничења слободе предузетништва регулисана је само у неким од анализираних устава. Уз друга уставом прописана ограничења права на предузетништво и својинских права само поједини устави изричито прописују да је очување и заштита животне средине или заштита добара од посебног еколошког значаја, основ ограничења слободе предузетништва. ${ }^{58}$ Специфичан вид заштите животне средине, природних богатстава и добара која може бити основ ограничења слободе предузетништва је и уставно регулисање својинских права на овим добрима и титулара својинских права (облици

54 Устав Македоније (члан 8, став 1, алинеје 8 и 10).

55 Устав Швајцарске (члан 73).

56 Устав Пољске (члан 74, став 1).

57 Устав Немачке (члан 20а).

58 Устави Црне Горе (члан 59), Хрватске (члан 52), Македоније (члан 55 став 3), Пољске (члан 31, став 3) Србије (члан 83, став 2), Републике Српске (члан 52). 
својине: државна својина ${ }^{59}$, државни монопол ${ }^{60}$, јавна својина, друштвена својина, приватна својина ${ }^{61}$ ) титулари својинских права државна својина ${ }^{62}$, државни монопол ${ }^{63}$, јавна својина, друштвена својина, приватна својина ${ }^{64}$, својинска права странаца ${ }^{65}$ ); посебан режим њиховог коришћења (законско регулисање режима коришћења ових ресурса ${ }^{66}$, концесије ${ }^{67}$ и могућност ограничења својинских права над овим добрима ${ }^{68}$, обазриво и рационално коришћење појединих добара $\left.{ }^{69}\right)$; посебна заштита ових добра ${ }^{70}$ и одговорност за заштиту (првенствено држава ${ }^{71}$ али и сви други субјекти ${ }^{72}$ ), елементарне непогоде као основ ограничења слободе предузетништва. ${ }^{73}$

3. Природни ресурси које устави идентификују, регулишу њихову заштиту и прописују посебан режим њиховог коришћења што јесу уједно и фактори ограничења слободе предузетништва. Међу уставима бележе се значајне разлике с обзиром на садржај, обим и квалитет уставног регулисања природних добара и природних ресурса који су значајни за здраву животну средину. Као заштићена природна добра и природни ресурси идентификују се и издвајају:

- Вазду⿰ $x^{74}$ као природни ресурс који се посебно штити и у вези са којим устави регулишу: утврђивање јединствене граничне емисионе вредности

59 Устави Бугарске (члан 18, став 1), Русије (члан 9, став 2).

60 Устав Бугарске (члан 18, став 2).

61 Устав Русије (члан 9, став 2).

62 Устави Бугарске (члан 18, став 1), Русије (члан 9, став 2).

63 Устав Бугарске (члан 18, став 2).

64 Устав Русије (члан 9, став 2).

65 Устав Бугарске (члан 22).

66 Устав Хрватске (члан 52, став 2).

67 Устав Бугарске (члан 18, став 5).

68 Устави Италије (члан 44), Русије (члан 36, ставови 2 и 3).

69 Устав Швајцарске (члан 89) регулише принципе коришћења енергије: „довољно, вишеструко, сигурно, економично и еколошко енергетско снабдевање“, „штедљиву и рационалну енергетску потрошњу“, „коришћење домаћих обновљивих енергија“, „развој енергетских техника, посебно уштеде енергије и обновљиве енергије“ и др.

70 Устав Македоније (члан 56).

71 Устави Хрватске (члан 52, став 1), Италије (члан 9, став 2).

72 Устав Црне Горе (члан 78).

73 Устав Пољске (члан 233, став 3, у вези са чланом 22)

74 Устави Аустрије (члан 10, став 1, тачка 11), Немачке (члан 74, став 1, тачка 24), Хрватске (члан 52). 
за материје штетне по ваздух ${ }^{75}$, прочишћавање ваздуха ${ }^{76}$, одржавање чистоће ваздуха ${ }^{77}$, ваздушни простор. ${ }^{78}$

- Вода ${ }^{79}$ се у већем броју устава препознаје као важан природни ресурс, али је садржај уставне регулативе различит. У неким уставима, поред бланкетне норме која воду одређује као ресурс који ужива посебну заштиту, ${ }^{80}$ посебан акценат се ставља на крајобални плажни појас, ${ }^{81}$ море, морску обалу и острва. ${ }^{82}$ У другим уставима се акценат ставља само на неке воде (морску обалу, ${ }^{83}$ обале, плаже, територијалне воде и природне изворе ${ }^{84}$, земљиште отето од мора ${ }^{85}$, мочваре ${ }^{86}$, канале и наводњавање ${ }^{87}$, минералне и термалне воде ${ }^{88}$, налазишта вода ${ }^{89}$ и посебно међународна и међукантонална налазишта вода ${ }^{90}$ ). Устави регулишу и друга питања значајна за режим вода и очување овог природног ресурса (изградња и коришћење хидрауличних постројења ${ }^{91}$, домаћинско коришћење и заштита налазишта воде ${ }^{92}$, одбрана од штетних утицаја вода, ${ }^{93}$ одржавање и откривање налазишта воде, коришћење вода за производњу енергије и за расхлађивање ${ }^{94}$, захвати у кружни ток вода ${ }^{95}$, доношење прописа о заштити

75 Устав Аустрије (члан 11, став 5).

76 Устав Немачке (члан 74, став 1, тачка 24).

77 Устав Аустрије (члан 10, став 1, тачка 11).

78 Устав Хрватске (члан 52).

79 Устави Бугарске (члан 18, став 1), Хрватске (члан 52), Немачке (члан 74, став 1 , тачка 17 и члан 91а, став 1), Шпаније (члан 132, став 2 и члан 148, став 1, тачка 10), Швајцарске (члан 76).

80 Устави Бугарске (члан 18, став 1) и Хрватске (члан 52).

81 Устав Бугарске (члан 18, став 1).

82 Устав Хрватске (члан 52).

83 Устав Немачке (члан 74, став 1, тачка 17 и члан 91а, став 1).

84 Устав Шпаније (члан 132, став 2).

85 Устав Белгије (члан 113).

86 Устав Белгије (члан 113).

87 Устав Шпаније (члан 148, став 1, тачка 10).

88 Устав Шпаније (члан 148, став 1, тачка 10).

89 Устав Швајцарске (члан 76, став 1).

90 Устав Швајцарске (члан 76, став 5).

91 Устав Шпаније (члан 148, став 1, тачка 10).

92 Устав Швајцарске (члан 76, став 1).

93 Устав Швајцарске (члан 76, став 1).

94 Устав Швајцарске (члан 76, став 2).

95 Устав Швајцарске (члан 76, став 2). 
вода, обезбеђењу одговарајућих заосталих количина воде, водоградњи, обезбеђивању насипа и утицају атмосферских талога ${ }^{96}$, надлежности регионалних власти везане за коришћење налазишта воде и могућност увођења пореза за коришћење налазишта воде ${ }^{97}$, коришћење вода за саобраћајна предузећа уз плаћање пореза за коришћење ${ }^{98}$, снабдевање водом $^{99}$, морски водени путеви и речни водени путеви од општег значаја 100 и др.).

Земља као важан природни ресурс регулише се у највећем броју анализираних устава. ${ }^{101}$ Акценат је на пољопривредном и обрадивом земљишту, начину коришћења овог земљишта (рационално и планско коришћење ${ }^{102}$, коришћење само у пољопривредне сврхе уз могућност промене намене земљишта само изузетно уколико је доказана потреба за тим, под условима и на начин прописан законом ${ }^{103}$, коришћење у складу са општим интересом посебно ако се ради о промени намене пољопривредног земљишта ${ }^{104}$, уређење земљишта ${ }^{105}$, побољшавање аграрне структуре ${ }^{106}$, регионалне институције за кредитирање пољопривреде и развој земљишта ${ }^{107}$ и др.), као и на заштити пољопривредног и обрадивог земљишта ${ }^{108}$. Посебно детаљно ово је регулисано у Уставу Швајцарске ${ }^{109}$.

96 Устав Швајцарске (члан 76, став 3).

97 Устав Швајцарске (члан 76, став 4).

98 Устав Швајцарске (члан 76, став 4).

99 Устав Немачке (члан 75, став 1, тачке 3 и 4).

100 Устав Немачке (члан 74, став 1, тачка 21).

101 Устави Аустрије (члан 14, ставови 1, 2, 4 и 5), Белгије (члан 113), Бугарске (члан 21), Хрватске (члан 52), Италије (члан 44 и члан 117, став 2), Немачке (члан 75, став 1, тачке 3,4 и 17), Пољске (члан 23), Русије (члан 9, став 2), Словеније (члан 71, став 1 и 2), Србије (члан 88, ст. 1), Шпаније (члан 47, став 1).

102 Устав Хрватске (члан 52).

103 Устав Бугарске (члан 21, став 2).

104 Устав Шпаније (члан 47, став 1).

105 Устав Немачке (члан 75, став 1, тачке 3 и 4).

106 Устав Немачке (члан 91а, став 1, тачка 3).

107 Устав Италије (члан 114, став 2).

108 Устави Аустрије (члан 14, став 1, 2, 4 и 5), Бугарске (члан 21), Немачке (члан 74, став 1, тачка 17), Пољске (члан 23), Словеније (члан 71, став 1 и 2), Србије (члан 88, став 1), Шпаније (члан 47, став 1 и члан 130, став 1).

109 Устав Швајцарске (члан 104) прописује да „1. Конфедерација води бригу о томе да пољопривреда једном континуираном тржишном производњом даје значајан допринос: А. сигурном снабдевању становништва; Б. одржавању природних услова за живот и неговању културе у сеоским пределима; Ц. децентралном насељавању 
Поједини устави начелно прописују да је земља „основно национално богатство које је под посебном заштитом државе и друштва“110 као и да се земља користи и чува „као основа живота и рада народа који живи на одговарајућој територији“111. Специфично решење садржи Устав Аустрије, који детаљно регулише школовање стручњака за област пољопривреде и шумарства ${ }^{112}$.

земље. 2. Као допуна очекиваној самопомоћи пољопривреде Конфедерација унапређује сеоска имања која обрађују земљу, а ако је то потребно и одступањем од начела слободне привреде. 3. Она своје мере усмерава тако да пољопривреда испуњава своје мултифункционалне задатке. Она има посебне дужности и задатке: А. допуњује сеоске приходе директним уплатама у циљу одговарајуће накнаде за показани учинак, под условом да могу да пруже доказе о еколошком раду; Б. економски исплативим изазовима унапређује облике производње који су блиски природи, животињама и еколошким принципима; Д. доноси прописе у вези са декларацијом о пореклу, квалитету, методама производње и поступцима за прераду животних намирница; Д. штити животну средину од угрожавања кроз прекомерно коришћење ђубрива, хемикалија и других помоћних материјала; Е. може да помаже у истраживању, саветовању и образовању у области пољопривреде, као и да пружи инвестициону помоћ; Ф. може да донесе прописе за учвршћивање сеоских поседа.

4. Она за то користи средства из области пољопривреде која су намењена у те сврхе, као и општа средства Конфедерације." (члан 104 - пољопривреда)

110 Устав Бугарске (члан 21, ст. 1).

111 Устав Русије (члан 9, став 2).

112 Устав Аустрије (члан 14, став 1, 2, 4, и 5) „1.У школству у области пољопривреде и шумарства као и у области пољопривредног и шумарског васпитања у пословима школских домова... доношење и спровођење закона је у покрајинској надлежности, уколико у другим ставовима није другачије одређено. Послови високог школства не спадају у области пољопривреде и шумарства. 2. У савезној надлежности је доношење закона и њихово спровођење у следећим пословима: а. виши пољопривредни и шумарски наставни заводи за образовање и усавршавање наставника пољопривредних и шумарских школа; б. стручне школе за образовање шумарског особља; ц. јавне пољопривредне и шумарске стручне школе које су у циљу обављања планом и програмом предвиђених вежби организационо повезане са неком од јавних школа или са неким савезним пољопривредним или шумарским огледним заводом; д. школски домови који су искључиво или претежно одређени за ученика под тачкама а. до д.; ђ. субвенције трошкова особља конфесионалних пољопривредних и шумарских школа; е. савезни пољопривредни и шумарски огледни заводи који су организационо повезани са пољопривредном или шумарском школом коју одржава Савез у циљу обављања планом и програмом предвиђених вежби у овим школама. 4. У савезној надлежности је доношење закона о принципима, у покрајинској надлежности је доношење закона о извршењу и њихово спровођење: а. у области пољопривредних и шумарских професионалних школа: у пословима како одређивања образовног циља и обавезних предмета и бесплатне наставе тако и пословима школске обавезе и преласка из школе једне покрајине у школу других покрајина; б. у области пољопривредних и шумарских професионалних школа: у пословима одређивања услова пријема, циља образовања, 
Рудна богатства (подземна богатства) као значајан развојни ресурс се различито регулишу у уставима, а терминологија је неуједначена. Рудна богатства или рударство изричито се помињу само у неколико устава ${ }^{113}$, док се у већини устава користе општи појмови чије значење је шире, као на пример: природна богатства ${ }^{114}$, природни ресурси ${ }^{115}$, добра од општег интереса ${ }^{116}$, природни извори ${ }^{117}$, природна баштина ${ }^{118}$ и сл. Норме су најчешће начелне и укључују све природне ресурсе. Изостаје ближе регулисање коришћења и заштите ових ресурса, или се упућује на законско регулисање ових питања. ${ }^{119}$ У више устава прописује се својински режим и начин коришћења ових добара. ${ }^{120}$ Само поједини устави ближе регулишу режим коришћења ових добара стављајући акценат на рационално коришћење ${ }^{121}$ или утврђују да се ова добра морају користити на начин да се заштите и побољшају услови живота и заштити и обнови животна средина ${ }^{122}$, односно да се овим ресурсима може слободно располагати под условом да се тиме не наноси „штета животној средини и не нарушавају права и законски интереси других лица" ${ }^{\prime 23}$.

облика организације, обима наставе и обавезних предмета, бесплатности наставе и преласка из школе једне покрајине у школу других покрајина; ц. пословима јавног права приватних пољопривредних и шумарских професионалних и стручних школа са изузетком школа које потпадају под ст. 2, тачка б. (стручне школе за образовање шумарског особља). 5. Формирање пољопривредних и шумарских школа и огледних завода дозвољено је само ако је покрајинска влада у покрајини, у којој стручна школа, односно огледни завод треба да има своје седиште, дала своју сагласност. Ова сагласност није неопходна ако се ради о формирању пољопривредне или шумарске стручне школе које треба да се организационо повежу са заводом за усавршавање и образовање наставника пољопривредних и шумарских школа у циљу обезбеђења планом и програмом предвиђених вежби."

113 На пример, у уставима Аустрије (чл. 10, ст. 1, тачка 10), Бугарске (чл. 18, ст. 1), Хрватске (чл. 52), Македоније (чл. 56, ст. 1), Шпаније (чл. 45, ст. 2)

114 Устави Македоније (чл. 56, ст. 1), Словеније (чл. 70, ст. 2 и 3), Србије (чл. 85, ст. 2).

115 Устав Русије (чл. 9, ст. 1).

116 Устав Србије (чл. 88, ст. 1).

117 Устав Шпаније (чл. 45, ст. 2).

118 Устав Црне Горе (чл. 78).

119 Устави Словеније (чл. 70, ст. 2 и 3), Србије (чл. 85, ст. 2).

120 На пример, устави Бугарске (чл. 22, ст. 1), Црне Горе (чл. 58, ст. 3 и чл. 59), Немачке (чл. 15), Русије (чл. 36, ст. 2), Словеније (чл. 70, ст. 3), Србије (чл. 85, ст. 1 и 2 и чл. 87, ст. 1 и 2), Шпаније (чл. 128 и чл. 131, ст. 1).

121 Устав Шпаније (чл. 45, ст. 2).

122 Устав Шпаније (чл. 45, ст. 2).

123 Устав Русије (чл. 36, ст. 2). 
Флора и фауна су неодвојиви део животне средине и предмет су уставне регулативе.Уставна решења разликују, с обзиром на садржај и обим уставне регулативе, као и добра на која се ставља акценат. У неким уставима се начелном одредбом прописује посебна заштита биљног и животињског света као и других делова природе ${ }^{124}$, природних резервата ${ }^{125}$, посебних екосистема ${ }^{126}$. У другим уставима акценат је на заштити појединих делова фауне, а посебно: шуме ${ }^{127}$, посебан режим и заштита шума, ${ }^{128}$ шумско земљиште ${ }^{129}$ и експлоатације шума ${ }^{130}$, пашњаци ${ }^{131}$, паркови од националног значаја ${ }^{132}$, планински предели ${ }^{133}$ укључујући и посебне мере за планинске зоне $\mathrm{e}^{134}$, континентални појас а посебно проучавање, разрада, коришћење, очување и привређивање, водећи рачуна о биолошким, минералним и енергетским ресурсима у тим морским пространствима, ${ }^{135}$ пешачке стазе и шеталишта ${ }^{136}$. У неким уставима регулише се заштита биља од болести и штеточина ${ }^{137}$, посебно заштита пољопривредног и шумског биља ${ }^{138}$, промет усева и биља ${ }^{139}$, ђубрива за биља и уређаји за заштиту биља, укључујући одобравање и признавање врста усева и биља ${ }^{140}$ и др.

Устави регулишу и производњу, промет, коришћење и руковање материјама и производима који могу угрозити животну средину. Све ове уставне одредбе постављају уједно и оквир у коме се остварује слобода

124 Устави Хрватске (чл. 52) и Македоније (чл. 56, ст. 1).

125 Устав Бугарске (чл. 18, ст. 1).

126 Устав Италије (чл. 117, ст. 1).

127 На пример, Устав Швајцарске (чл. 77) „1. Конфедерација води бригу о томе да шуме могу да испуне своје функције у погледу заштите, коришћења и благостања. 2. Она утврђује принципе о заштити шума. 3. Она унапређује мере за одржавање шума.“. 128 Устави Аустрије (чл. 10, ст. 1, тачка 10), Бугарске (чл. 18, ст. 1), Хрватске (чл. 52), Немачке (чл. 74, ст. 1, тачка 17), Швајцарске (чл. 77).

129 Устав Србије (чл. 88, ст. 1).

130 Устав Шпаније (чл. 148, ст. 1, тачка 8).

131 Устав Аустрије (чл. 10, ст. 1, тачка 10).

132 Устав Бугарске (чл. 18, ст. 1).

133 Устав Шпаније (чл. 130, ст. 3).

134 Устав Италије (чл. 44).

135 Устав Бугарске (члан 18, став 2).

136 Устав Швајцарске (члан 88).

137 Устави Аустрије (члан 12, став 1, тачка 4) и Немачке (члан 74, став 1, тачка 20).

138 Устав Немачке (члан 74, став 1, тачка 20).

139 Устави Аустрије (члан 10, став 1, тачка 11) и Немачке (члан 11 а, став 1, тачка 20).

140 Устав Аустрије (члан 10, став 1, тачка 11). 
предузетништва и фактор су њеног ограничења. Предмет регулативе je: руковање опасним и осталим отпадом ${ }^{141}$, производња и руковање фармацеутским производима ${ }^{142}$, производња радиоактивних производа, оружја, експлозивних материја и материја са снажним биолошким дејством $^{143}$, уклањање смећа, прочишћавање ваздуха и борба против буке ${ }^{144}$, руковање лековима и опојним средствима, организмима, хемикалијама и предметима који могу да угрозе здравље ${ }^{145}$, утврђивање јединствених граничних емисионих вредности за материје штетне по ваздух и одржавање чистоће ваздуха ${ }^{146}$, транспорт течног или гасовитог горива или погонског материјала ${ }^{147}$, мере за спречавање опасних оптерећивања човекове околине која настају прекорачењем граничних емисионих вредности ${ }^{148}$, режим производње, трговине, држања и коришћења оружја и експлозива ${ }^{149}$, производња, набавка, продаја, увоз, извоз и пролаз ратног материјала ${ }^{150}$ и др. Посебан пример је Устав Аустрије ${ }^{151}$ који, поред осталог, регулише контролу и надзор над применом прописа који се односе на материје опасне по животну средину.

Природне лепоте, реткости и знаменитости и њихово очување и заштита, такође, чине уставну материју која се регулише начелним одредбама ${ }^{152}$ које одређују границе у којима се остварује слобода предузетништва.

141 Устав Аустрије (члан 10, став 1, тачка 11).

142 Устав Шпаније (члан 163, став 1, тачка 16).

143 Устав Бугарске (члан 18, став 4).

144 Устав Немачке (члан 74, став 1 тачка 24)

145 Устав Швајцарске (члан 118)

146 Устав Аустрије (члан 10, став 1, тачка 11 и члан 11, став 5).

147 Устав Швајцарске (члан 91).

148 Устав Аустрије (члан 10, став 1, тачка 11).

149 Устав Шпаније (члан 149, став 1, тачка 26).

150 Устав Швајцарске (члан 107, став 2).

151 Устав Аустрије (члан 11, тачка 9) прописује да „Савезна влада и поједини савезни министри имају следећа овлашћења: 1 . овлашћење да преко савезних органа стичу увид у акте покрајинских органа; 2 . овлашћење да захтевају извештаје о примени закона и уредби донетих на савезном нивоу; 3.овлашћење да захтева све информације о спровођењу неопходне за припрему и доношење савезних закона и уредби; 4 . овлашћење да у нарочитим случајевима захтева информације и увид у акте, уколико је то неопходно за примену других овлашћења."

152 Устави Црне Горе (члан 78), Македоније (члан 56), Италије (члан 9, став 2), Немачке (члан 75, став 1, тачка 3), Русије (члан 9, став 1), Словеније (члан 73, став 1), Србије (члан 89, став 1), Шпаније (члан 45), Швајцарске (члан 78). 
Енергија и различити извори енергије предмет су уставне регулативе која се односи на: рационално коришћење, производњу, пренос и дистрибуцију енергије, мере безбедности и трасе јаке струје, нацрте изградње и коришћење хидрауличних постројења ${ }^{153}$. Неколико устава ${ }^{154}$ посебно регулишу атомску енергију као енергетски извор, њену производњу и коришћење уз изричито наглашавање да се она користи у мирнодопске сврхе $\mathrm{15}^{155}$, заштиту од опасности насталих ослобађањем атомске енергије или јонизираним зрацима и уклањање радиоактивних материја и др. Устав Швајцарске $\mathrm{e}^{156}$ је илустративан пример и за ову област. Поред тога неки устави регулишу још и: храну, контролу хране и животних намирница ${ }^{157}$, посебан режим саобраћаја тешких возила у циљу заштите животне

153 Устави Аустрије (члан 10, став 1, тачке 9 и 10 и члан 12, став 1), Италије (члан 117, став 2), Швајцарске (члан 89 и члан 91), Шпаније (члан 45 и члан 149, став 1, тачка 21), Немачке (члан 74, став 1, тачка 11a).

154 Устави Аустрије (члан 10, став 1, тачке 10 и 11), Бугарске (члан 18, став 4), Немачке (члан 74, став 1, тачка 11a), Швајцарске (чланови 90 и 118).

155 Устав Немачке (члан 74, став 1, тачка 11a).

156 Устав Швајцарске (члан 89) прописује: „1. Конфедерација и кантони се у оквиру својих надлежности залажу за довољно, вишеструко, сигурно, економично и еколошко енергетско снабдевање, као и за штедљиву и рационалну енергетску потрошњу. 2. Конфедерација утврђује принципе о коришћењу домаћих обновљивих енергија и о штедљивом и рационалном искоришћењу енергије. 3. Конфедерација доноси прописе о потрошњи енергије, постројењима, возилима и уређајима. Она унапређује развој енергетских техника, поготово у областима уштеде енергије и обновљивих енергија. 4. За мере које се тичу потрошње енергије у зградама, надлежни су пре свега кантони. 5. Конфедерација у својој енергетској политици узима у обзир настојања кантона и општина као и привреде, она узима у обзир и односе у појединим пределима земље и економску подношљивост." Поред тога, Устав (чл. 91) регулише и транспорт енергије: „1. Конфедерација доноси прописе о транспорту и испоруци електричне енергије. 2. Законодавство о цевоводима за транспорт течног или гасовитог горива или погонског материјала су предмет Конфедерације“, и прописује надлежност конфедерације у области атомске енергије (чл. 90).

157 Устави Аустрије (члан 10, став 1, тачка 11), Италије (члан 117, став 2), Немачке (члан 74, став 1, тачка 20), Швајцарске (члан 104, став 3, тачка ц). 
средине $^{158}$, порез на собраћај тешких возила ${ }^{159}$, мере заштите животне средине и природе од последица друмског саобраћаја ${ }^{160}$, заштиту животне средине од угрожавања због прекомерног коришћења ђубрива, хемикалија и других помоћних материјала ${ }^{161}$ и др.

\section{8. Закључак}

Увид у компаративну уставност упућује на неколико закључака.

Прво, право на предузетништво и слободу предузетништва данас гарантује велики број устава као и услове који стварају подесан амбијент за остваривање овог права (једнаки правни услови за обављање привредних делатности, самосталност привредних субјеката, слободно кретање роба, услуга и финансијских средстава, развијање конкуренције и подршка конкуренцији, одговорност привредних субјеката за преузете обавезе и др.).

Друго, право на предузетништво остварује се у границама прописаним уставом. Границе у којима се ово право остварује постављају људска права, принцип социјалне правде и на њега ослоњена уставна ограничења везана посебно за својински режим, титуларе својинских права и начин коришћења својине, специфичне забране (антимонополска клаузула) и заштита неких посебних права (заштита потрошача, право на здраву животну средину).

Треће, у контексту уставног начела да је здрава животна средина одговорност јавних власти према будућим генерацијама, као развојни ресурси који уживају посебну уставну заштиту издвајају се вода, ваздух, земља, рудна богатства, флора и фауна, енергија чије коришћење и

158 Устав Швајцарске (члан 84) регулише транзитни саобраћај тешких возила преко Алпа: „1. Конфедерација штити Алпску област од негативних поседица транзитног саобраћаја. Она оптерећеност транзитним саобраћајем ограничава на једну меру која није штетна за људе, животиње и биљке као и животне просторе. 2. Транзитни робни саобраћај преко Алпа од границе до границе одвија се железницом. Савезно веће доноси неопходне мере. Изузеци су дозвољени само ако се не могу избећи. Они морају да буду законом ближе објашњени. 3. Капацитет транзитних путева у Алпској области не сме да се повећава. Од овог ограничења изузети су заобилазни путеви који растерећују насељена места од транзитног саобраћаја“.

159 Устав Швајцарске (члан 85, став 1) утврђује право на увођење пореза на саобраћај тешких возила у зависности од снаге и потрошње.

160 Устав Швајцарске (члан 86, став 3, тачка д).

161 Устав Швајцарске (члан 104, став 3, тачка д). 
заштита је предмет уставне регулативе и која уједно поставља границе остваривања права на предузетништво.

Четврто, иако још нису обликовани стандарди у конституционализацији права на здраву животну средину, па се решења у компаративној уставности разликују по приступу уставној регулативи, одређењу садржине ових права, обиму и садржају уставне регулативе и др. увид у компаративна искуства упућује на закључак да је легитимно, корисно и потребно отворити дебату о конституционализацији принципа одрживог развоја. Поред начела владавине права и начела социјалне правде, принцип одрживог развоја који је за заједницу једнако значајан, могао би наћи своје место у уставима у не тако далекој будућности. 
Marijana Pajvančić, LL. D.

Full Professor (retired),

Faculty of Law, University of Novi Sad

\title{
CONSTITUTIONALIZATION OF THE RIGHT TO ENTREPRENEURSHIP AND RELATED RIGHTS
}

\begin{abstract}
Summary
This paper is a working basis for reviewing the constitutional guarantees and the manner of constitutional regulation of developmental resources and the capacity of society in comparative constitutionality. The aim of this contibution is to provide insight into the experiences of comparative constitutionality and how the constitutions regulate the issues important for the development of society in order to improve the constitutional regulation of development issues in the context of the solution contained in the Constitution of the Republic of Serbia. The key issue important for considering the constitutionalization of development issues is the constitutional regulation of the right to entrepreneurship and econimic actitity, the scope and content of the constitutional guarantee of these rights, with reference to the limitations of these rights, in particular restrictions that are based on equally important rights - the right to a healthy life and the right to healthy living environment, which also entail the protection of natural resources and the environment.

The following constitutions have been used as examples of comparative constitutionality: the constitutions of Austria, Belgium, Bulgaria, Bosnia and Herzegovina, Montenegro, Denmark, France, Croatia, Italy, Macedonia, Germany, Poland, Russia, Republika Srpska, Slovenia, Slovakia, Serbia, Switzerland, and Spain. In the selection of constitutions whose provisions were included in the research, several criteria were taken into account: the choice included the constitutions of the EU member states, the constitutions of the former socialist countries that are now members of the European Union, the constitutions of the countries of the region, the constitutions of the countries which are currently in the the process of negotiations with the European Union, and the constitutions of the countries which used to be part of the same (federal) state until the dissolution of the SFRY. Such a choice of constitutions provides an opportunity to consider various social and political contexts in which constitutional rules were created, to examine the specific constitutional solutions in a wider context and, thus, provide a more comprehensive insight into these solutions.
\end{abstract}

Keywords: comparative constitutional law, right to entrepreneurship, human rights. 